\title{
Impact of Work Life Balance on Organizational Commitment of University Teachers: Evidence from Jashore University of Science and Technology
}

\author{
Arifa Akter*1, Mohammad Awal Hossen², Md. Nazrul Islam ${ }^{3}$ \\ ${ }^{1}$ Department of Accounting and Information Systems, Jashore University of Science and Technology, \\ Jashore, Bangladesh \\ ${ }^{2}$ Department of Management, Jashore University of Science and Technology, Jashore, Bangladesh \\ ${ }^{3}$ Department of Finance and Banking, Jashore University of Science and Technology, Jashore, Bangladesh

\begin{abstract}
:
Increased imbalance between work and family life of university teachers is an alarming issue now-a-days. The purpose of this study is to investigate the relationship between work life balance and organizational commitment of teaching employees of Jashore University of Science and Technology in Bangladesh. Data has been collected from 80 respondents through a questionnaire survey. Pearson correlation and regression model have been developed based on this dataset to get the result. The result shows that significant number of teachers perceived there is a positive impact of work life balance on the level of commitment towards their organization. This study certainly answers the question regarding the impact of work life balance on organizational commitment of the teaching employees. This research paper may serve the policymakers of educational sectors to pay attention to the proper work life balance of university teachers in order to motivate them to participate in quality higher education. Moreover, further studies are encouraged to analyze the impact of work life balance by incorporating all the stakeholders of an organization which may help to generalize the findings of this study
\end{abstract}

Keywords: Work Life Balance, Organization, Family, Commitment, University Teachers, JUST

\section{Introduction}

Organizational commitment of university teachers involves not only in participating academic activities but also a rigorous involvement in research activities which sometimes may create imbalance between their personal and organizational responsibilities. Ensuring work life balance is crucial especially for university teachers as they have to spend time to research activities even at home whereas they supposed to spend those times with their family. Academicians have to be engaged more in intellectual activities than other professionals because it may lead to mental stress and therefore resulting poor level dedication unless they have a proper balance between professional and family life. Work life balance implies the degree of involvement of the job and family activities which has become a vital issue now-a-days for organizational stakeholders. Managing organizational and personal needs may influence the productivity and satisfaction level of an employee which reflects the level of commitment of employees to the organization(Veenhoven, 1991). University teachers are responsible to prepare competent graduates for making the nations better off. Having stressed in work life balance, it would be tough for the teachers to concentrate on research and academic activities. Therefore, it earns great importance to find out the relationship between work life balance and organizational commitment of university teachers and thus solve the problems associated with this issue(Komal Saeed, 2014). The main objective of the study is to examine the impact of work life balance of university teachers on the level of commitment towards their organization. The study 
further aims to identify the extent of the relationship between work life balance and organizational commitment of the teachers of Jashore University of Science and Technology (JUST) located at Jashore in Bangladesh. The area of this research is limited as it is investigated on only teachers of a particular university of a specific region of the country for which the results cannot be generalized. The sample of the study is only teachers of the organization but not all the employees of the university which makes it difficult to reflect the perception of all the related employees of the organization. However, existing literature suggests that numerous studies exhibit the importance of work life balance and job commitment. That's why, the authors are convinced to state research question for this particular issue as following:

What is the significance and extent of the relationship between work life balance and organizational commitment?

\section{Literature Review}

The concept of work life balance has gained considerable attention in the last few years (Deery, 2008), but, however, it has also been found that less attention has been given in the issues relating to work life balance in the field of the tertiary educational sector (Doherty \& Manfredi, 2006; Mohd Noor \& Amat, 2010; Noor, 2011). Work life balance refers to the equal engagement in and satisfaction with both occupational roles and personal responsibilities (Greenhaus, Collins, \& Shaw, 2003). Work life balance is about having a good fit between professional roles and other personal activities that are crucial to people like leisure and personal activities, family responsibilities, community roles and recreation. Maintaining a balance between the job and personal responsibilities has become a challenge for many people working in different professions. The more a person is preoccupied with job responsibilities, the higher will be the work-family conflict which leads to job dissatisfaction, lower commitment and increased psychological distress (Adams et.al. 1996).

Organizational commitment refers to the extent to which a person is committed to the accomplishment of an organization's objectives, and it includes the levels of employee's involvement, loyalty and engagement with the values of the organization (Caught \& Shadur, 2000). It can also be depicted as the employee's readiness to exert extra level of effort for the organization, willingness to maintain membership in the organization and the relative intensity of identification with and involvement in a specific organization (Mowday et. al., 1982). Organizational commitment consists of three dimensions: affective, normative and continuance commitment (Meyer \& Allen, 1991).

A number of studies have been conducted showing the relationship between work-family balance and some specific behavioral job outcomes such as organizational commitment and job satisfaction (Doherty and Manfredi 2006; Kinnie, Hutchinson, Purcell, Rayton and Swart 2005; Scholarios \& Marks, 2004). Organizational commitment and work-family balance both are crucial because, they affect the organizational effectiveness and family well-being. Increased strain at job place negatively affects job satisfaction, organizational commitment and work life balance (Kossek, 2005; Bragger et. al.,2005). A positive relationship has been found between work life balance, organizational commitment and job satisfaction. Whereas good work life balance is negatively related with intention to leave the organization(Noor K. M., 2011). Employees find it comfortable to work in an organization that helps them to balance between the needs of job life and the needs of personal life. Developing policies that lead to greater work life balance satisfaction promotes organizational productivity and reduces turnover (Moore, 2007). According to the study of Kinnie et al. (2007), organizational efforts that help employees to maintain a good balance between work and family life have a positive impact on the commitment level of employees at all groups.

The relative importance of maintaining a balance between job place needs and personal life needs is gaining momentum among workers around the world and the academics involved with higher education is not an exception (Stanton, Noor, \& Young, 2009). Failure to balance between work and family responsibilities is a common scenario among 
university teaching employees. They showed higher discontent with the work-life balance than other professionals which further leads to job dissatisfaction and psychological distress and has negative impact on their job performane (Anderson, Morgan, \& Wilson, 2002). When dispute occurs between work and family roles among the academics it also impacts the quality of tertiary education (Elliot, 2003). Kinman(2008) found that more than half of the university teachers surveyed said that they had to usually preoccupied with official work at home after leaving the job place which cause stress. Teaching is a noble and dignified profession. The success of every nation depends upon the quality of its students and the quality of its education. It is also important to look at the ways how the students are getting education. If the academics are not satisfied with their work and life and have to work under stress, they will not be able to produce good students. Social exchange theory also supports this issue. When people are able to maintain a balance between work and family life, they will exert extra effort for the organization beyond their normal duties and obligation. The study is therefore carried out to show the impact of work life balance on organizational commitment of teaching employees. So, the hypothesis can be drawn as following:

$H_{1}$ : There is positive relationship between work life balance and organizational commitment.

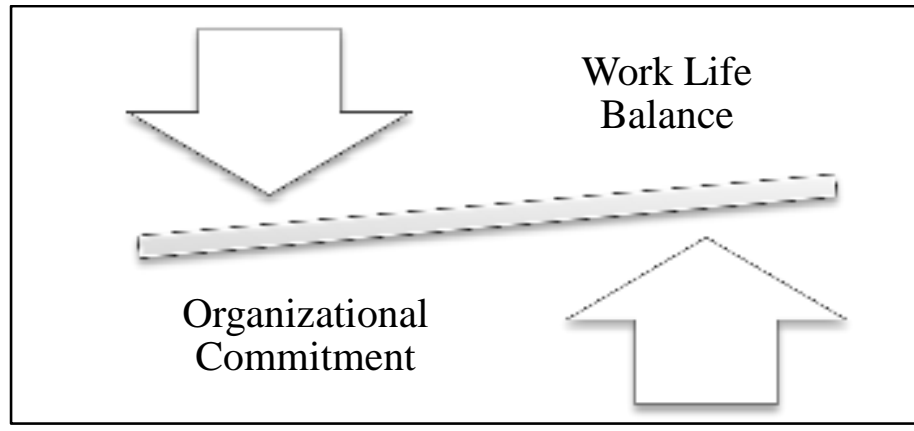

Diagram 1: Conceptual Model of Work Life Balance and Organizational Commitment

\section{Methodology}

The study is descriptive in nature and the variables used in the study are work life balance and organizational commitment to satisfy the objectives of the study. All the teachers of Jashore University of Science and Technology are the population of the study. Respondents are selected through simple random sampling (R. Burke Johnson, 2010) as it reflects the unbiased results of the study. For collecting primary data a questionnaire survey has been conducted as a tool for this study as it is a suitable technique to analyze the perception of human behavior(Francis, 2004). Out of total population, only 80 teachers respond to the survey questionnaire and accordingly the study considers it as sample size of the study. The questionnaire consists in three parts in which demographic varibles such as gender, age, designation, marital status, eductaion and teaching experience are included in the very first part of the questionnaire. Consecutively, the second and last section of the questionnaire comprises eight items(NING, 2004) in each addressing the factors of determining the perception of work life balance and organizational commitment. Items of the questionnaire were measured through five point Likert Scale ranges from strongly agree to strongly disagree where items are ranked as following:

$$
\text { Strongly Agree }(S A)=1 \text {, Agree }(A)=2 \text {, }
$$

$\operatorname{Neutral}(N)=3$, Disagree $(D)=4$ and Strongly

$$
\text { Disagree }(S D)=5
$$

Secondary data has been collected from related research journals, books, magazines, conference paper and websites to make the study more comprehensive. The data has been analyzed by using SPSS software to get the result of the study. Descriptive statistics has been computed for identifying the demographic profile of the respondents. Furthermore, to investigate the existence of relationship between the variables, pearson correlation test has been conducted. Lastly, to examine the hypothesized relationships of work life balance and organizational commitment, a linear regresion model has been developed as following:

$\mathrm{Y}=\mathrm{a}+\mathrm{bX}+\mathrm{e}$

$(\mathrm{Y}=$ Organizational commitment, $\mathrm{a}=$ intercept, $\mathrm{b}=$ slope, $\mathrm{X}=$ work life balance, $\mathrm{e}=$ error term) 
Table 1: Demographic Profile (Data Source: Questionnaire Survey)

\begin{tabular}{|l|l|l|l|}
\hline Variables & & $\begin{array}{l}\text { Percentage } \\
(\%)\end{array}$ & $\begin{array}{l}\text { Frequency( } \\
\text { N) }\end{array}$ \\
\hline \multirow{5}{*}{ Gender } & Male & 78.8 & 63 \\
\cline { 2 - 4 } & Female & 21.3 & 17 \\
\hline \multirow{5}{*}{ Age } & $\begin{array}{l}\text { Less that } \\
\text { 25 years }\end{array}$ & 1.3 & 1 \\
\cline { 2 - 4 } & $\begin{array}{l}\text { 25-34 } \\
\text { years }\end{array}$ & 82.5 & 64 \\
\cline { 2 - 4 } & $\begin{array}{l}35-44 \\
\text { years }\end{array}$ & 11.3 & 9 \\
\cline { 2 - 4 } & $\begin{array}{l}45-54 \\
\text { years }\end{array}$ & 3.8 & 3 \\
\cline { 2 - 4 } & $\begin{array}{l}\text { 55 years } \\
\text { or above }\end{array}$ & 1.3 & 1 \\
\hline \multirow{5}{*}{$\begin{array}{l}\text { Marital } \\
\text { Status }\end{array}$} & Single & 33.8 & 27 \\
\cline { 2 - 4 } & Married & 65.0 & 52 \\
\cline { 2 - 4 } & Divorced & 1.3 & 1 \\
\cline { 2 - 4 } & Widowed & 0 & 0 \\
\hline \multirow{5}{*}{} & Professor & 3.8 & 3 \\
\hline
\end{tabular}

\begin{tabular}{||l|l|l|l|}
\hline \multirow{5}{*}{$\begin{array}{l}\text { Designatio } \\
\text { Education }\end{array}$} & $\begin{array}{l}\text { Associate } \\
\text { Professor }\end{array}$ & 8.8 & 7 \\
\cline { 2 - 4 } & $\begin{array}{l}\text { Assisstant } \\
\text { Professor }\end{array}$ & 28.8 & 23 \\
\cline { 2 - 4 } & Lecturer & 58.8 & 47 \\
\hline & Bachelor & 10.0 & 8 \\
\cline { 2 - 4 } & Master & 73.8 & 59 \\
\cline { 2 - 4 } & PhD & 16.3 & 13 \\
\cline { 2 - 4 } Experience & Others & 0 & 0 \\
\hline & $\begin{array}{l}\text { Less than } \\
1 \text { year }\end{array}$ & 7.5 & 6 \\
\cline { 2 - 4 } & $\begin{array}{l}\text { 6-10 years } \\
\text { years }\end{array}$ & 73.8 & 59 \\
\cline { 2 - 4 } & $\begin{array}{l}10 \text { years } \\
\text { above }\end{array}$ & 3.8 & 12 \\
\hline
\end{tabular}

From Table 1 we get a statistics regarding the Associate Professor. Furthermore 16.3\% demographic variables of the study. This table starts with male-female participants ratio which is imbalanced to some extent (Male was $78.8 \%$ and Female was $21.3 \%$ ). The majority of the respondents belongs to age group of 25-34 years and hold the marital status of being married. Among all the contributors $3.8 \%$ worked as Professor, $58.8 \%$ were lecturer and another $37.6 \%$ belongs to Assistant and respondents have $\mathrm{PhD}$ Degree, $73.8 \%$ have Master Degree and $10 \%$ have Bachelor Degree as their highest level of academic degree. Out of total respondents $73.8 \%$ have 5 years of working experience, 6-10 years experience group consist of $15 \%$ respondents and rest of $11.3 \%$ belongs to other experience group.

Table 2: Correlation Analysis (Data Source: Authors' Computation)

\begin{tabular}{|ll|l|l|}
\hline & & Work Life Balance & Organizational Commitment \\
\hline Work Life Balance & Pearson Correlation & 1 & .293 \\
& Sig. (Two tailed) & & .008 \\
& $\mathrm{~N}$ & 80 & 80 \\
\hline Organizational Commitment & Pearson Correlation & .293 & 1 \\
& Sig. (Two tailed) & .008 & \\
& $\mathrm{~N}$ & 80 & 80 \\
\hline
\end{tabular}

Here we look for the relationship between work life balance and organizational commitment. Correlation coefficients are always between -1 and 1 and tell us the strength of the linear relationship between our variables. If we look at the table, we can see here the correlation coefficient is .293 which denotes almost a moderate strength positive correlation as the value is positive. The second thing we want to look at the significance value .008 and if compare it with our level of significance we find that this is smaller than our level of significance that is chosen as .050; which means that the correlation 
is statistically significant. We are using statistics because we have a sample not population, so in our sample we observed a small positive correlation and there is enough evidence to say that this correlation exists in the population. As the calculated significance value is less than our level of significance ( $\mathrm{p}$ value 0.050 ), we are able to say that there is enough evidence to suggest that the correlation we observed does exist in the population.

Table 3: Regression Analysis

Table 3(a): ANOVA $^{\mathrm{a}}$

(Data Source: Authors' Computation)

\begin{tabular}{|c|c|c|c|c|c|c|c|}
\hline \multicolumn{2}{|c|}{ Model } & \multirow{2}{*}{\begin{tabular}{|l} 
Sum of Squares \\
5.700 \\
\end{tabular}} & \multirow{2}{*}{$\begin{array}{l}\mathbf{d f} \\
1\end{array}$} & \multirow{2}{*}{\begin{tabular}{|l} 
Mean Square \\
5.700 \\
\end{tabular}} & \multirow{2}{*}{$\begin{array}{r}\mathbf{F} \\
7.351 \\
\end{array}$} & \multirow{2}{*}{$\begin{array}{r}\text { Sig. } \\
.008^{b} \\
\end{array}$} & \multirow{2}{*}{\begin{tabular}{c}
\multicolumn{1}{c}{$\mathbf{R}$} \\
Square \\
.086
\end{tabular}} \\
\hline \multirow[t]{3}{*}{1} & \multirow{3}{*}{$\begin{array}{l}\text { Regression } \\
\text { Residual } \\
\text { Total }\end{array}$} & & & & & & \\
\hline & & 60.479 & 78 & .775 & & & \\
\hline & & 66.179 & 79 & & & & \\
\hline
\end{tabular}

a. Dependent Variable: Organizational Commitment

b. Predictors: (constant), Work Life Balance

The ANOVA table lets us know if our model is a significant model. What it means for a model to be significant is the predictor variables (in this case only one variable work life balance) a good predictor of the outcome variable (in this case Organizational Commitment). We determine that by looking at significance value of our model. In this case our significance value is .008 , this is less than
Alpha .05 therefore the model is significant. We would report the model significant as $F(1,78)=$ $7.351, \mathrm{P}=.008$. We can look at the $\mathrm{R}^{2}$; it gives the percentage of the variance in the dependent variable explained by the independent variable. In this case we would say that $8.6 \%$ of all of the variance in Organizational Commitment can be explained by one's level of Work life Balance.

Table 3(b): Coefficients (Data Source: Authors' Computation)

\begin{tabular}{|c|c|c|c|c|c|c|}
\hline \multirow{2}{*}{\multicolumn{2}{|c|}{ Model }} & \multicolumn{2}{|c|}{ Unstandardized Coefficients } & \multirow{2}{*}{\begin{tabular}{|l}
$\begin{array}{c}\text { Standardized } \\
\text { Coefficients }\end{array}$ \\
Beta
\end{tabular}} & \multirow{2}{*}{$\mathbf{t}$} & \multirow{2}{*}{ Sig. } \\
\hline & & B & Std. Error & & & \\
\hline 1 & $\begin{array}{l}\text { (Constant) } \\
\text { Work life Balance }\end{array}$ & $\begin{array}{l}1.786 \\
.163\end{array}$ & $\begin{array}{l}.227 \\
.060\end{array}$ & .293 & $\begin{array}{l}7.853 \\
2.711\end{array}$ & $\begin{array}{l}.000 \\
.008\end{array}$ \\
\hline
\end{tabular}

a. Dependent Variable: Organizational Commitment

Table 3 (b) gives us the regression coefficients. To write the equation for the line that uses Work life Balance to predict Organizational Commitment we are going to look at our Unstandardized Coefficients. 0.163 is the slope (beta) for Work life Balance, 1.786 in the constant line is the Y intercept, that means the equation in the line for using Work life Balance for predicting Organizational Commitment would be $\mathrm{Y}=1.786+.163 *$ Work life
Balance. To determine whether or not the slope of Work life Balance is significant we go over to the significant value and see that $\mathrm{T}$ test comparing that slope to a slope of 0 is $\mathrm{T} 2.7$ with a significant value of .008 and therefore the result is significant. The significance level also provides enough evidence to accept the alternate hypothesis which denotes that there is positive relationship between work life balance and organizational commitment. 


\section{Conclusion}

The main purpose of the study was to investigate the impact of work life balance on organizational commitment of teachers of a public university in Bangladesh. Extensive literature review has been conducted to support the related theory and filling up the knowledge gap. Descriptive statistics, correlation analysis and regression analysis are computed from the questionnaire survey data to get the result which would make a base upon which the

\section{References}

1. Adams, A. G., King, L. A., \& King, D. W. (1996). Relationships Of Job And Family Involvement, Family Social Support, And Work-Family Conflict With Job And Life Satisfaction. Journal Of Applied Psychology , 4 (4), 411-420.

2. Anderson, D., Morgan, B., \& Wilson, J. (2002). Perceptions Of Family Friendly Policies: University Versus Corporate Employees. Journal Of Family And Economic Issues , 2 (3), 73-92.

3. Bragger, J., Rodriguez-Srednicki, O., Kutcher, E., Indovino, L., \& Rosner, E. (2005). Workfamily Conflict, Work-Family Culture, And Organizational Citizenship Behavior Among. Journal Of Business And Psychology , 20 (2), 303-324.

4. Caught, K., \& Shadur. (2000). The Measurement Artifact In The Organizational Commitment Questionnaire. Psychological Reports , 87, 777-788.

5. Deery, M. (2008). Talent Management, Work-Life Balance And Retention Strategies. International Journal Of Contemporary Hospitality Management , 20 (7), 792-806.

6. Doherty, L., \& Manfredi, S. (2006). Action Research To Develop Work-Life Balance In A Uk University. Women In Management Review , 21 (3), 241-59.

7. Elliot, M. (2003). Work And Family Role Strain Among University Employees. Journal Of Family And Economic Issues , 24 (2), 157-180.

8. Francis, J. J. (2004). Constructing Questionnaires Based On The Theory Of Planned Behaviour A Manual For Health Services Researchers. hypothesis can be tested. Based on the above results, it can be concluded that work life balance has positive impact on organizational commitment of university teachers. Organization and family should be supportive to a teacher so that he can be more committed to his organization as well as his family. As the study takes into account the evidence from only one public university of Bangladesh, there is scope for the researchers to extend the study by incorporating both public and private universitie

9. Greenhaus, J., Collins, K., \& Shaw, J. (2003). The Relation Between Work-Family Balance And Quality Of Life. Journal Of Vocational Behavior, 63, 510-31.

10. Kinman, G., \& Jones, F. (. (2008). A Life Beyond Work? Job Demands, Work-Life Balance, And Wellbeing In Uk Academics. Journal Of Human Behavior In The Social Environment, 17 (1), 41-60.

11. Kinnie, N., Hutchinson, S., Purcell, J. R., \& Swart, J. (2005). Satisfaction With $\mathrm{Hr}$ Practices And Commitment To The Organisation: Why One Size Does Not Fit All. Human Resource Management Journal, 15 (4), 9-29.

12. Komal Saeed, Y. A. (2014). Examining The Relationship Between Work Life Balance, Job Stress And Job Satisfaction Among University Teachers (A Case Of University Of Gujrat). International Journal Of Multidisciplinary Sciences And Engineering , 5 (6), 9-15.

13. Kossek, E. E. (2005). Workplace Policies And Practices To Support Work And Families. In S. Bianchi, L. Casper, \& R. King (Eds.). Work, Family Health And WellBeing, 97-116.

14. Meyer, J., \& Allen, N. (1991). A ThreeComponent Conceptualization Of Organizational Commitment. Human Resources Management Review , 1 (1), 8189.

15. Mohd Noor, K., \& Amat, M. (2010). Keseimbangan Kerja Dan Kehidupan Dan Kepuasan Kerja Ahli Akademik Di Institusi Pengajian Tinggi Malaysia. Paper Presented To Leadership And Management Seminar, Nilai, Negeri Sembilan.

16. Moore, F. (2007). Work-Life Balance: Contrasting Managers And Workers In An Mnc. Employee Relations , 29 (4), 385-99. 
17. Mowday, R. P. (1982). EmployeeOrganization Linkage: The Psychology Of Commitment, Absenteeism, And Turnover. New York: Academic Press .

18. Ning, T. (2004). Antecedents And Consequences Of Role Stress In Hospitality Industry. National University Of Singapore , Department Of Management And Organization, Singapore.

19. Noor, K. M. (2011). Work-Life Balance And Intention To Leave Among Academics In Malaysian Public Higher Education Institutions. International Journal Of Business And Social Science , 1-9.

20. Noor, K. M. (2011). Work-Life Balance And Intention To Leave Among Academics In Malaysian Public Higher Education Institutions. International Journal Of Business And Social Science, 2 (11), 240248.
21. R. Burke Johnson, L. C. (2010). Educational Research:Quantitative, Qualitative And Mixed Approaches (5th Ed.). Sage.

22. Scholarios, D., \& Marks, A. (2004). WorkLife Balance And The Software Worker. Human Resource Management Journal , 14 (2), 54-74.

23. Stanton, P. M., Noor, K. M., \& Young, S. H. (2009). Work-Life Balance And Job Satisfaction : A Study Among Academics In Malaysian Higher Education Institutions. 14th Asia Pacific Management Conference (Apmc): Enhancing Sustainability In The Asia Pacific: Entrepreneurship And Innovation (Pp. 1-15). Surabaya, Indonesia: Airlangga University.

24. Veenhoven, R. (1991). Is Happiness Relative? Springerlink, 24 (1), 1-34. 